\title{
Genetic variation in productivity, leaf traits and carbon isotope discrimination in hybrid poplars cultivated on contrasting sites
}

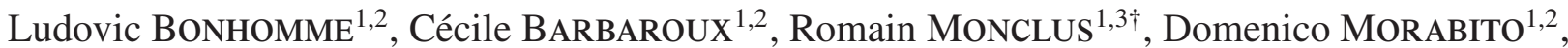 \\ Alain BERTHELOT ${ }^{4}$, Marc VILLAR ${ }^{5}$, Erwin DREYER ${ }^{3}$, Franck BRIGNOLAS ${ }^{1,2 *}$ \\ ${ }^{1}$ Université d'Orléans, UFR-Faculté des Sciences, Laboratoire de Biologie des Ligneux et des Grandes Cultures, UPRES EA 1207, rue de Chartres, \\ BP 6759, 45067 Orléans Cedex 02, France \\ ${ }^{2}$ INRA, USC2030 ‘Arbres et Réponses aux Contraintes Hydrique et Environnementales’ (ARCHE), 45067 Orléans, France \\ ${ }^{3}$ INRA, Nancy Université, UMR1137 INRA-UHP ‘Écologie et Écophysiologie Forestières', IFR 110 'Génomique, Écophysiologie \\ et Écologie Fonctionnelle', INRA Nancy, 54280 Champenoux, France \\ ${ }^{4}$ FCBA, station Nord-Est, 60 route de Bonnencontre, 21170 Charrey-sur-Saône, France \\ ${ }^{5}$ INRA, UR ‘Amélioration, Génétique et Physiologie Forestières', BP 20619, Ardon, 45166 Olivet Cedex, France
}

(Received 15 November 2007; accepted 3 March 2008)

\begin{abstract}
-
- We examined the relationships between productivity, leaf traits and carbon isotope discrimination in bulk leaf matter $\left(\Delta_{\mathrm{l}}\right)$ and in phloem sap $\left(\Delta_{\mathrm{s}}\right)$ from more than 5-year-old trees belonging to Populus deltoides $\times$ P. nigra and Populus trichocarpa $\times$ P. deltoides; trees were grown in alluvial and non alluvial sites in a commercial poplar plantation.

- On both sites, a large genetic variability was evidenced for all variables. The genotypic ranking remained stable between years for all variables, while it differed between sites. $\Delta_{\mathrm{l}}$ scaled positively with $\Delta_{\mathrm{S}}$ and neither $\Delta_{\mathrm{l}}$ nor $\Delta_{\mathrm{S}}$ were correlated with productivity. A significant genotype by site interaction was evident for all variables. The non alluvial site resulted in lower productivity, and in thicker/denser leaves with lower nitrogen and carbon contents. Noteworthy, the genotypic ranking for $\Delta_{\mathrm{l}}$ measured at the alluvial site was similar to that previously established in a glasshouse.

- As observed in previous studies from younger trees, there is a potential to select genotypes, combining high productivity and high water-use efficiency, for growth in moderately drought-prone areas.
\end{abstract}

hybrid poplars plantation / soil characteristics / genetic variability / carbon isotope discrimination $(\Delta)$ / leaf traits

Résumé - Variation génétique de la productivité, de caractères foliaires et de la discrimination isotopique vis-à-vis du carbone chez des hybrides de peuplier cultivés sur des sites contrastés.

- La productivité, des caractères foliaires et la discrimination isotopique vis-à-vis du carbone de la matière organique des feuilles $\left(\Delta_{1}\right)$ et de la sève élaborée $\left(\Delta_{\mathrm{S}}\right)$ ont été étudiés chez Populus deltoides $\times$ P. nigra et Populus trichocarpa $\times$ P. deltoides à partir d'arbres âgés de plus de cinq ans, cultivés en peupleraie sur des sites alluviaux et non alluviaux.

- Des différences génotypiques ont été observées pour toutes les variables. Le classement des génotypes était conservé entre deux années, alors qu'il variait entre sites une année donnée. $\Delta_{\mathrm{l}}$ était corrélé positivement avec $\Delta_{\mathrm{s}}$ et aucun lien n’a été détecté entre $\Delta_{\mathrm{l}}$ ou $\Delta_{\mathrm{s}}$ et productivité. Une interaction significative entre génotype et site a été observée pour toutes les variables. Les arbres du site non alluvial se caractérisaient par une plus faible productivité et des feuilles plus épaisses/denses avec des teneurs en azote et en carbone plus faibles. De façon intéressante, le classement des génotypes pour $\Delta_{1}$ était maintenu entre les expériences réalisées sur site alluvial et celles précédemment menées en serre.

- Toutes expériences confondues, il semble possible de sélectionner des génotypes productifs et efficients afin d'étendre les plantations à des terrains enclins à des sécheresses modérées.

peupleraie / caractéristiques du sol / variabilité génétique / discrimination isotopique vis-à-vis du carbone $(\Delta)$ / caractères foliaires

\section{INTRODUCTION}

Poplars are among the fastest growing trees under temperate latitudes. Their high productivity is associated with a tight dependency upon water availability (Barigah et al., 1994; Ceulemans et al., 1988; Tschaplinski and Blake, 1989; Tschaplinski et al., 1994; Zsuffa et al., 1996). Poplar cultivation tends to extend from flood plains and bottomlands towards

* Corresponding author: franck.brignolas@univ-orleans.fr

$\dagger$ In memoriam (September 2006). uplands where soil water availability is subjected to seasonal changes. To sustain this trend, it might be useful to select cultivars with improved water-use efficiency over the growth cycle. Intrinsic water-use efficiency $\left(\mathrm{W}_{\mathrm{i}}\right)$, i.e., the ratio between net $\mathrm{CO}_{2}$ assimilation and stomatal conductance, is an important component of this efficiency which may be indirectly estimated at leaf level, via the carbon isotope discrimination $(\Delta)$ (Farquhar and Richards, 1984; Farquhar et al., 1989; Monclus et al., 2006; Ponton et al., 2001). A large genetic variability of $\Delta$ has already been reported among poplar genotypes (Marron et al., 2005; Monclus et al., 2005 and 2006; Zhang et al., 2004). 
The selection of genotypes combining a satisfactory productivity and high water-use efficiency would be a considerable advantage for growth in moderately drought-constrained areas, as stated by Braatne et al. (1992) for poplar and by Condon et al. (2002) for cereals.

The links between productivity and $\Delta$ differ according to poplar species: a positive relationship was found for Populus davidiana (Dode) Schneider (Zhang et al., 2004), whereas none was detected for Populus trichocarpa $\times$ P. deltoides (TD hybrids) and Populus deltoides $\times$ P. nigra (DN hybrids) (Marron et al., 2005; Monclus et al., 2005; 2006; Rae et al., 2004). The lack of correlation observed for these two hybrids suggests the possibility to select genotypes displaying simultaneously a high productivity and water-use efficiency.

A detailed study with several commercial poplar genotypes (DN hybrids) grown as young cuttings in glasshouse (3month-old rooted cuttings; Marron et al., 2005) or in a nursery (1 to 4-year-old rooted cuttings coppiced each year; Monclus et al., 2005; 2006) indicated consistent genotypic differences in $\mathrm{W}_{\mathrm{i}}$, and a lack of correlation between $\mathrm{W}_{\mathrm{i}}$ and productivity. The stability of these observations remains to be established under a wider range of environmental conditions and with older trees, as some juvenility effects might interfere with the observed ranking. Therefore, we have extended the comparative approach to trees at least 5 years old grown in a commercial poplar plantation for wood production, and managed with conventional forestry practices. Tested clones were genotypes of DN hybrids and TD hybrids. Two sites were chosen in the plantation according to soil water availability and fertility. Genetic variability was studied on alluvial and non alluvial sites on the basis of 12 and 11 genotypes, respectively. The site effect was quantified by comparing 9 genotypes common to both sites. Comparisons with previous experiments carried out in glasshouse and in nursery were done using 9 DN genotypes. The productivity of each tree was computed as the ratio between the circumference measured at $1.30 \mathrm{~m}$ height and the age of the tree; leaf traits encompassed specific leaf area and carbon and nitrogen contents; carbon isotope discrimination was used as a surrogate for intrinsic water-use efficiency.

\section{MATERIAL AND METHODS}

\subsection{Study site}

The experiment was carried out in the commercial poplar plantation of Le Moulin de Bariteau (Vienne, France, $47^{\circ} 7^{\prime}$ N, $0^{\circ} 10^{\prime} \mathrm{E}$; $36 \mathrm{~m}$ a.s.l.) which extends over 200 ha and includes about 34000 hybrid poplar trees. The climate is oceanic, characterized by mild temperatures $\left(11.1^{\circ} \mathrm{C}\right.$ annual mean $)$ and a constant distribution of precipitation (650 $\mathrm{mm}$ per year for the last three decades) (Météo France, http://www.meteofrance.com). The poplar plantation occupies both sides of the Chavenay river, upstream of its junction with the Négron river and the adjacent slopes.

Soil fertility and soil water availability were analysed during 1994, for areas located on the river banks and for areas located on adjacent slopes, by the Association Forêt Cellulose (AFOCEL) in the Laboratoire de la chambre d'agriculture de la Sarthe (LARCA 72, Le Mans, France). Data related to soil characteristics are available at http://www.peupliersdefrance.org/indexbariteau.htm. Soil fertility was rated according to its cationic exchange capacity (CEC; meq. $100 \mathrm{~g}^{-1}$ ) and its saturation rate (S/CEC; \%); ratio between soil base cationic content (S; meq. $100 \mathrm{~g}^{-1}$ ) and CEC. Maximal available soil water $\left(\mathrm{PAW}_{\mathrm{M}} ; \mathrm{mm}\right)$ was assessed from soil texture (Jamagne et al., 1977). Based on LARCA data, two sites, named alluvial and non alluvial, were selected for the present study. The alluvial site displayed a CEC above 40 meq. $100 \mathrm{~g}^{-1}$, a S/CEC of $100 \%$, a $\mathrm{PAW}_{\mathrm{M}}$ above $250 \mathrm{~mm}$ and the level of the water table near the soil surface year round; this zone was restricted to the banks of the Chavenay. The non alluvial site displayed a CEC below 23 meq. $100 \mathrm{~g}^{-1}$, a S/CEC of about $90 \%$ and a $\mathrm{PAW}_{\mathrm{M}}$ ranging from 100 to $200 \mathrm{~mm}$; this site was on the adjacent slopes.

\subsection{Plant material}

Fourteen poplar genotypes including 10 Populus deltoides $\times$ P. nigra (DN hybrids) and 4 Populus trichocarpa $\times$ P. deltoides (TD hybrids) were selected; among them, 9 grew on both sites (Tab. I). Overall, 357 trees were studied; their age ranged from 6 to 14-year-old and their height varied from 14 to $28 \mathrm{~m}$. All trees were grown at $7 \times 7 \mathrm{~m}$ spacing.

\subsection{Plant measurements}

From July 18 to 21, 2005, one mature leaf was collected from the lowest branch of each tree and six calibrated discs $\left(2 \mathrm{~cm}^{2}\right)$ were cut from each lamina. Discs were dried at $60{ }^{\circ} \mathrm{C}$ during two days, weighted and specific leaf area (SLA, $\mathrm{cm}^{2} \mathrm{~g}^{-1}$ ) was computed. During the same period, phloem sap was collected from each tree with the method described by Scartazza et al. (2004) and modified by Gessler et al. (2004). On July 19, from 11:00 a.m. to 5:00 p.m., a thin strip of bark (2 $\mathrm{cm}$ long and $1 \mathrm{~cm}$ wide) still attached to the trunk was removed and plunged into tubes filled with $1 \mathrm{~mL}$ pure water for $4 \mathrm{~h}$. This mixture was membrane filtered ( $0.45 \mu \mathrm{m}$ pore size, Millipore), put into tin capsules and oven-dried at $60{ }^{\circ} \mathrm{C}$ over one day. From July 10 to July 13, 2006, the sampling was repeated from mature leaves of trees grown in the alluvial site only. During November 2006, the productivity of each tree was estimated as the mean annual radial increment (RI, $\mathrm{mm} \mathrm{y}^{-1}$; i.e., the ratio between the circumference measured at $1.30 \mathrm{~m}$ height and the age of the tree), assuming a circular section of the trunk.

Carbon isotope composition $\left(\delta^{13} \mathrm{C}\right)$ and carbon and nitrogen contents $\left(\mathrm{C}_{\mathrm{M}}, \mathrm{N}_{\mathrm{M}} ; \mathrm{mg} \mathrm{g}_{\mathrm{DW}}^{-1}\right)$ of bulk leaf material were assessed from $1 \mathrm{mg}$ homogenous dry powder obtained from the oven-dried calibrated discs. $\delta^{13} \mathrm{C}$ of phloem sap was analysed from the dried phloem extracts. These analyses were conducted by the Scottish Crop Research Institute (Dundee, Scotland, UK) from a CF-IRMS (Europa Scientific ANCA-NT 20-20 Stable Isotope Analyser with ANCANT Solid/Liquid Preparation Module, Europa Scientific Ltd., Crewe, UK). $\delta^{13} \mathrm{C}$ was calculated relative to Pee Dee Belemnite limestone standard as described in Craig (1957):

$$
\delta^{13} \mathrm{C}=\frac{\left(R_{\text {sample }}-R_{\text {standard }}\right)}{\left(R_{\text {standard }}\right)} \times 1000(\%),
$$

where $R_{\text {sample }}$ and $R_{\text {standard }}$ are the ${ }^{13} \mathrm{C} /{ }^{12} \mathrm{C}$ ratio in plant tissue and the standard, respectively. Carbon isotope discrimination $\left(\Delta_{\mathrm{l}}\right.$ and $\Delta_{\mathrm{s}}$ 
Table I. Plant material description including hybrid crosses, genotypes, abbreviations, origins and the number of trees used for each genotype and for each type of site. The age (years) of trees are indicated into brackets.

\begin{tabular}{|c|c|c|c|c|c|}
\hline \multirow[b]{2}{*}{ Hybrid } & \multirow[b]{2}{*}{ Genotype } & \multirow[b]{2}{*}{ Abbreviation } & \multirow[b]{2}{*}{ Origin } & \multirow{2}{*}{$\begin{array}{c}\text { Alluvial site } \\
\text { Number of tree (Age) }\end{array}$} & \multirow{2}{*}{$\begin{array}{c}\text { Non alluvial site } \\
\text { Number of tree (Age) }\end{array}$} \\
\hline & & & & & \\
\hline \multirow{10}{*}{$P$. deltoides $\times P$. nigra } & $\mathrm{A} 4 \mathrm{~A}$ & $\mathrm{~A} 4$ & Italy & $10(6)$ & \\
\hline & Brenta & $\mathrm{Bt}$ & Italy & & $6(5)+10(6)$ \\
\hline & Dorskamp & Ds & The Netherlands & $10(6)$ & $10(5)$ \\
\hline & I214 & $\mathrm{I} 2$ & Italy & $10(7)$ & $30(7)$ \\
\hline & $\mathrm{I} 45 / 51$ & I4 & Italy & $10(9)$ & $9(10)+10(14)$ \\
\hline & Koster & Ks & The Netherlands & $9(6)$ & \\
\hline & Lambro & $\mathrm{Lb}$ & Italy & & $9(5)+10(6)$ \\
\hline & Luisa-Avanzo & $\mathrm{La}$ & Italy & $9(7)$ & \\
\hline & Mella & Ml & Italy & $9(6)$ & $4(5)$ \\
\hline & Soligo & $\mathrm{Sg}$ & Italy & $9(6)$ & $3(5)$ \\
\hline \multirow{4}{*}{ P. trichocarpa $\times P$. deltoides } & Beaupré & $\mathrm{Bp}$ & Belgium & $10(9)+10(8)$ & $20(12)$ \\
\hline & Boelare & $\mathrm{B} 1$ & Belgium & $10(9)$ & $30(7)+10(13)$ \\
\hline & Hunnegen & $\mathrm{Hn}$ & Belgium & $10(7)$ & $30(7)$ \\
\hline & Raspalje & Rs & Belgium & $10(8)$ & $10(5)+10(6)+10(8)+10(7)$ \\
\hline
\end{tabular}

for bulk leaf matter and phloem sap respectively, \%o) was calculated according to Farquhar and Richards (1984), as:

$$
\Delta=\frac{\left(\delta_{\text {air }}-\delta_{\text {plant }}\right)}{\left(1+\left(\delta_{\text {plant }} / 1000\right)\right)}(\% o),
$$

where $\delta_{\text {air }}$ and $\delta_{\text {plant }}$ are $\delta^{13} \mathrm{C}$ of the atmospheric $\mathrm{CO}_{2}$ (assumed to be close to $-8 \%$ ) and the sample, respectively.

\subsection{Statistical analyses}

Results were analysed with the SPSS statistical software package (SPSS, Chicago, IL, USA) and with R software (version 2.0.1, A Language and Environment, Copyright 2004). For each variable, the normality of the distribution was tested with a Shapiro-Wilk test. Levels of significance were $* P \leqslant 0.05, * * P \leqslant 0.01$, *** $P \leqslant 0.001$ and $n s=$ non significant. Genotypic means are expressed with their standard error.

Genetic variability was evaluated for each site by a two-way ANOVA using the following model: $Y_{i j k}=\mu+H_{i}+H_{i}\left(G_{j}\right)+\varepsilon_{i j k}$; where $Y_{i j k}$ refers to individual values, $\mu$ is the general mean, $H_{i}$ is the effect of hybrid cross $i, H_{i}\left(G_{j}\right)$ is the effect of genotype $j$ in hybrid cross $i$ and $\varepsilon_{i j k}$ is the error. For each site, relationships between variables were computed by linear correlation (Pearson's coefficients), and illustrated by a principal component analysis (PCA) using genotypic means. The variables were standardized and orthogonal factors (= F1 and F2 axis) were successively built as linear combinations of these variables to maximize the fraction variability explained by these factors. Variables were first represented on the plane defined by the two main factors of the PCA; their coordinates were their linear correlation coefficients (Pearson's coefficient) with these factors. Variables projected as supplementary variables in the main plane F1 $\times$ F2 were obtained by computing linear correlations between these variables and scores F1 and F2 obtained from the initial PCA.

Station effect was evaluated by a three-way ANOVA using the following model: $Y_{i j k l}^{\prime}=\mu+H_{i}+H_{i}\left(G_{j}\right)+S_{k}+H_{i} \times S_{k}+H_{i}\left(G_{j}\right) \times S_{k}+\varepsilon_{i j k l}$; where $Y_{i j k l}^{\prime}$ refers to individual values, $\mu$ is the general mean, $H_{i}$ is the effect of hybrid cross i, $H_{i}\left(G_{j}\right)$ is the effect of genotype $j$ in hybrid cross $i, S_{k}$ is the site effect, $H_{i} \times S_{k}$ is the hybrid cross by site interaction, $H_{i}\left(G_{j}\right) \times S_{k}$ is the genotype in hybrid cross by site interaction and $\varepsilon_{i j k l}$ is the error. This analysis was performed with the 9 genotypes common to both sites; noteworthy, each genotype displayed the same age on alluvial and non alluvial sites (Tab. I).

Crossing comparisons with previous studies realized in our research unit were analysed by rank correlation (Spearman's coefficient), from DN hybrids. As a whole, 9 genotypes were common with previous studies; among them 7 belonged to the alluvial site (Dorskamp, I214, I45/51, Koster, Luisa-Avanzo, Mella and Soligo) and 7 belonged to the non alluvial site (Brenta, Dorskamp, I214, I45/51, Lambro, Mella and Soligo).

\section{RESULTS}

\subsection{Genetic variability in the alluvial site}

During 2005 and 2006, significant differences were recorded between DN hybrids and TD hybrids for all variables, except for $\Delta_{\mathrm{S}}$ measured in 2005 and for $\Delta_{1}$ measured in 2006 (Fig. 1). Overall, DN hybrids displayed higher values of RI, $\mathrm{N}_{\mathrm{M}}$ and $\mathrm{C}_{\mathrm{M}}$ than TD hybrids, while they displayed the lowest values of SLA and $\Delta_{1}$, at least during 2005. A significant genotype effect within hybrid cross was detected for all variables in 2005 and 2006. With all genotypes grouped, the genotype ranking (Spearman coefficients, $r_{s}$ ) remained stable from 2005 to 2006 for $\mathrm{N}_{\mathrm{M}}\left(r_{s}=0.59 *\right)$, SLA $\left(r_{s}=0.92 * * *\right)$ and $\Delta_{1}\left(r_{s}=0.84 * *\right)$ whereas it varied significantly for $\mathrm{C}_{\mathrm{M}}\left(r_{s}\right.$ $\left.=0.46^{\mathrm{ns}}\right)$. In 2005 , genetic variability was of the same magnitude for $\Delta_{1}$ and for $\Delta_{\mathrm{S}}$ with values ranging from $20.1 \%$ o to $22.3 \%$ and genotypic ranking remained comparable between $\Delta_{\mathrm{l}}$ and $\Delta_{\mathrm{S}}\left(r_{s}=0.68^{*}\right)$. Values measured for SLA and 


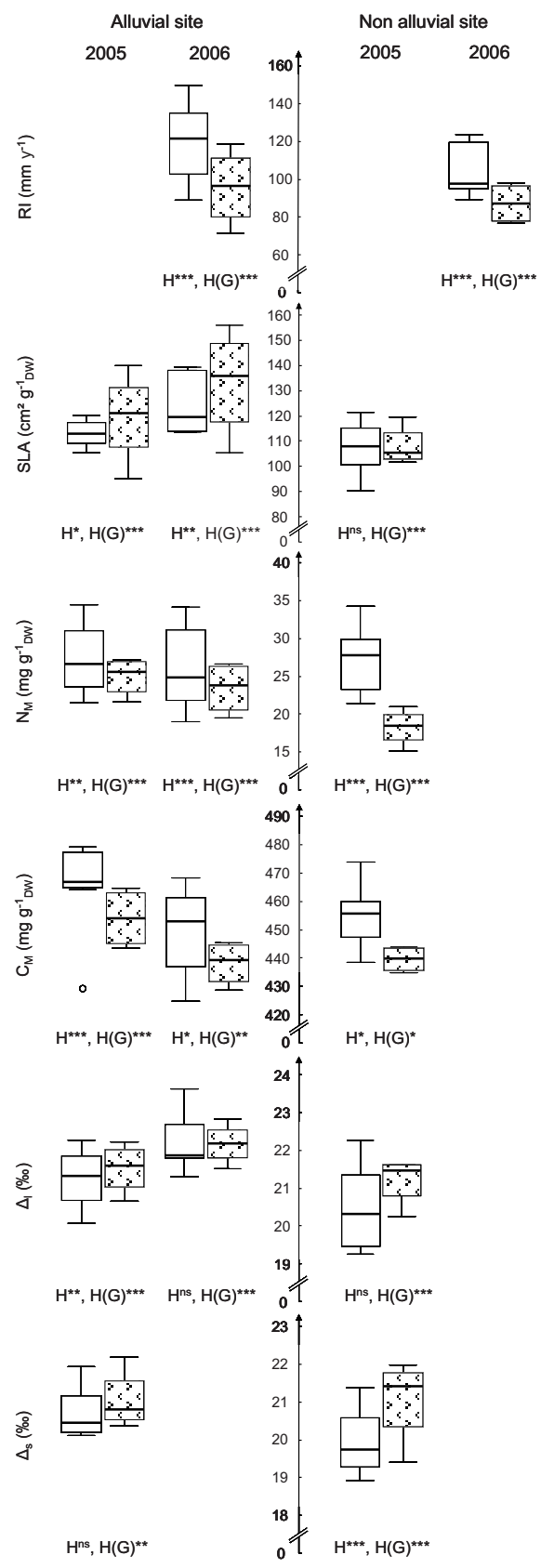

Figure 1. Genetic variability of productivity, leaf traits and variables related to water-use efficiency in DN hybrids (white boxes) and TD hybrids (hyphenated boxes) from two sites, during 2005 and 2006. Sites were alluvial ( 8 DN hybrids and 4 TD hybrids) and non alluvial (7 DN hybrids and 4 TD hybrids). Box plots are shown for mean annual radial increment $\left(\mathrm{RI}, \mathrm{mm} \mathrm{y}^{-1}\right)$, specific leaf area (SLA, $\left.\mathrm{cm}^{2} \mathrm{~g}_{\mathrm{DW}}^{-1}\right)$, leaf nitrogen and carbon contents $\left(\mathrm{N}_{\mathrm{M}}\right.$ and $\left.\mathrm{C}_{\mathrm{M}}, \mathrm{mg} \mathrm{g}_{\mathrm{DW}}^{-1}\right)$, and leaf and phloem sap carbon isotope discrimination $\left(\Delta_{\mathrm{l}}\right.$ and $\Delta_{\mathrm{s}}$, respectively, \%o). Each box represents the quartile below (Q1) and above (Q3) the median value. Vertical bars show minimum and maximum values except for genotypes away from 1.5 times from the top of the inter-quartile (Q3-Q1) range. Values outside this range are represented by open circles. Levels of significance are indicated for the hybrid cross effect $(\mathrm{H})$ and for the genotype in hybrid cross one $[\mathrm{H}(\mathrm{G})]$ (ns $=$ non significant; $* P \leqslant 0.05 ; * * P \leqslant 0.01 ; * * * P \leqslant 0.001$ ).
$\Delta_{1}$ were significantly higher in 2006 than in 2005; these differences could be explained by a higher cumulated rainfall (computed between January and August of each year) in 2006 than in 2005 (350 mm vs. $224 \mathrm{~mm}$ ) (Chambre d'agriculture d'Indre et Loire, http://www.indre-et-loire.chambagri.fr). Genetic variability was of the same magnitude during the two years for $\Delta_{1}(2.3 \%$ ), while it was higher in 2006 than in 2005 for SLA.

With all genotypes grouped, the main factorial plane of the PCA $(\mathrm{F} 1 \times$ F2 , Figs. $2 \mathrm{a}$ and $2 \mathrm{~b})$ explained $68.8 \%$ of the genetic variability, with $39.9 \%$ for $\mathrm{F} 1$ alone, while the $\mathrm{F} 3$ axis did not differentiate the genotypes (data not shown). Two independent groups of variables were identified from the $\mathrm{F} 1 \times \mathrm{F} 2$ plane (Fig. 2a). The first one included $\Delta_{\mathrm{l}}$ and $\Delta_{\mathrm{S}}$ and the second one $\mathrm{RI}$ and $\mathrm{N}_{\mathrm{M}}$. In each group, the variables were positively correlated (Tab. II). There was no clear grouping among genotypes in the F1 $\times$ F2 plane (Fig. 2b). Genotypes Koster and Dorskamp displayed high RI whereas Hunnegen displayed the lowest one; Raspalje had high values of $\Delta$ whereas Mella and Soligo displayed the lowest values. Interestingly, we were unable to detect any correlation between RI and $\Delta$ (Tab. II). The projection on the main plane $(\mathrm{F} 1 \times \mathrm{F} 2)$ of the variables measured in 2006, as supplementary variables, showed a similar distribution to 2005 except for $\mathrm{C}_{M}$ (Fig. 2a).

\subsection{Genetic variability in the non alluvial site - comparison with the alluvial site}

During 2005, significant differences were recorded between DN hybrids and TD hybrids for RI, $N_{M}, C_{M}$ and $\Delta_{\mathrm{s}}$ (Fig. 1). Overall, DN hybrids displayed higher values of RI, $\mathrm{N}_{\mathrm{M}}$ and $\mathrm{C}_{\mathrm{M}}$ than TD hybrids, while they displayed the lowest values of $\Delta_{\mathrm{s}}$. A significant genotype in hybrid cross effect was detected for all variables (Fig. 1). With all genotypes grouped, genotypic ranking remained comparable between $\Delta_{1}$ and $\Delta_{\mathrm{S}}$ $\left(r_{s}=0.86^{* *}\right)$. The main plane of the general PCA $(\mathrm{F} 1 \times$ F2), performed at genotypic level (Figs. 2c and 2d), explained $90.8 \%$ of the genetic variability, with $63 \%$ for F1 alone, while the $\mathrm{F} 3$ axis did not differentiate the genotypes (data not shown). Three groups of variables were defined from the F1 $\times$ F2 plane (Fig. 2c); the first group included $\Delta_{\mathrm{l}}$ and $\Delta_{\mathrm{s}}$, the second one $\mathrm{N}_{M}$ and $\mathrm{C}_{M}$ and the third one included SLA and RI. The F1 axis of the PCA opposed $\Delta\left(\Delta_{1}\right.$ and $\left.\Delta_{s}\right)$ to $N_{M}$ and $C_{M}$; within each group, variables were positively correlated while they were negatively correlated between groups (Tab. II). The F2 axis was defined by SLA and RI, but these variables did not correlate (Tab. II). Genotypes I214, I45/51 and Boelare displayed a high RI, a large SLA and high values of $\Delta_{1}$ and $\Delta_{\mathrm{S}}$ while Raspalje, Dorskamp, Mella and Brenta displayed low values of RI, SLA, $\Delta_{\mathrm{l}}$ and $\Delta_{\mathrm{s}}$; Soligo and Lambro displayed low values of $\Delta_{\mathrm{l}}$ and $\Delta_{\mathrm{S}}$ while Beaupré and Hunnegen were characterized by high values of $\Delta_{1}$ and $\Delta_{\mathrm{S}}$ (Fig. 2d). Interestingly, we were unable to detect any correlation between RI and $\Delta$ (Tab. II).

A significant site effect was detected for all variables except $\Delta_{\mathrm{S}}$ and $\Delta_{\mathrm{l}}$ (Appendix A1). Values recorded for RI, SLA, $\mathrm{N}_{M}$ and $\mathrm{C}_{M}$ were significantly lower in the non alluvial site. 


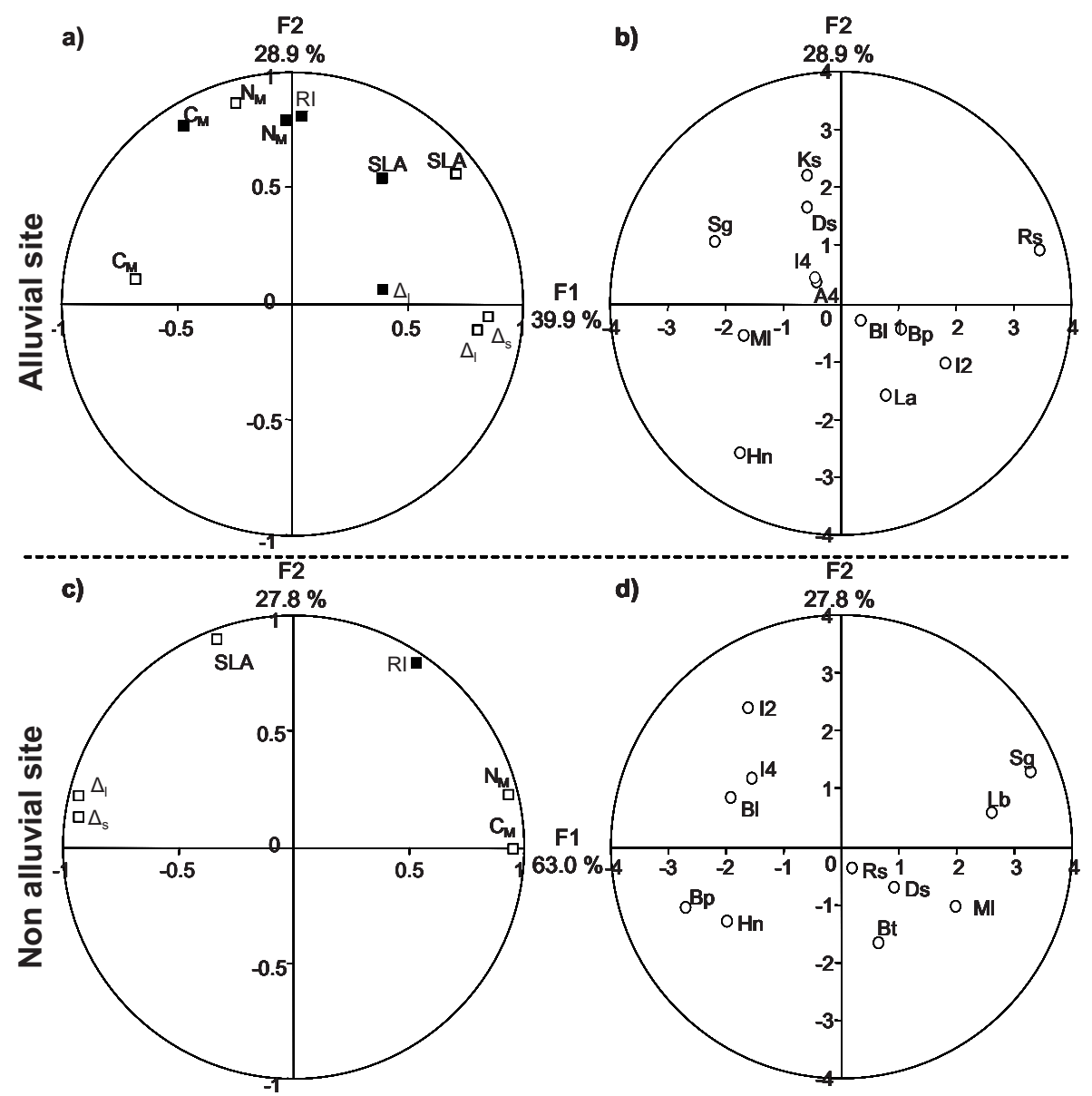

Figure 2. Factorial analysis (Principal Components Analysis) of genetic variability measured in the alluvial (a and b) and non alluvial sites (c and d). For the alluvial site, the distribution of 10 variables (a) and the projection of the 12 hybrid poplars genotypes (b) are shown in the main factorial plane F1 $\times$ F2 of PCA. F1 and F2 are linear combinations of the 5 variables measured during 2005 (white squares) plus mean annual radial increment (RI) measured in 2006 (black square). The others variables recorded during 2006 in the alluvial site (black squares) were projected as supplementary variables on the main F1 $\times$ F2 plane. For the non alluvial site, the distribution of 6 variables (c) and the projection of the 11 hybrid poplar genotypes (d) are shown in the main factorial plane F1 $\times$ F2 of a PCA. F1 and F2 are linear combinations of the 5 variables measured during 2005 (white squares) plus mean annual radial increment (RI) measured in 2006 (black square). See Table I for genotype abbreviations.

A significant hybrid cross by site interaction was detected for $\mathrm{N}_{\mathrm{M}}$ and SLA only (Appendix A1). TD hybrids displayed greater decrease in $\mathrm{N}_{M}$ and SLA than DN hybrids. A significant genotype in hybrid cross by site interaction was observed for all variables (Appendix A1). With all genotypes grouped, genotypic ranking varied significantly for RI, SLA, $\Delta_{\mathrm{l}}, \Delta_{\mathrm{S}}$ and $\mathrm{C}_{\mathrm{M}}$, while it remained stable for $\mathrm{N}_{\mathrm{M}}\left(r_{s}=0.68^{*}\right)$.

\subsection{Comparison of field grown trees with rooted cuttings grown under either nursery (Monclus et al., 2005 and 2006) or glasshouse (Marron et al., 2005) conditions}

Although growth conditions, plant size and age of the plants largely differed among the experiments, the genetic variability detected during experiments was of similar magnitude for all leaf traits, except SLA. SLA displayed a greater variability and higher values in the glasshouse $\left(190<\operatorname{SLA}\left(\mathrm{cm}^{2} \mathrm{~g}_{\mathrm{DW}}^{-1}\right)<235\right.$; Marron et al., 2005) than in the nursery $\left(104.4<\right.$ SLA $\left(\mathrm{cm}^{2}\right.$ $\left.\left.\mathrm{g}_{\mathrm{DW}}^{-1}\right)<126.3\right)$ or in the poplar plantation $\left(90.3<\mathrm{SLA}_{2005}\right.$ $\left.\left(\mathrm{cm}^{2} \mathrm{~g}_{\mathrm{DW}}^{-1}\right)<121.3\right)$. In all experiments, the productivity index did not correlate with $\Delta$ measured from bulk leaf dry matter. Only one significant and positive correlation was detected between values of $\Delta_{1}$ measured in 2005 or 2006 in the alluvial site and values previously measured in glasshouse from younger cuttings (Fig. 3).

\section{DISCUSSION}

Compared to TD hybrids, DN hybrids displayed the highest productivity (estimated via RI), the highest water-use efficiency (estimated via $\Delta$ ) and thicker/denser leaves (estimated 
Table II. Linear correlations (Pearson's coefficients) between mean annual radial increment (RI, $\mathrm{mm} \mathrm{y}^{-1}$ ), specific leaf area (SLA, $\mathrm{cm}^{2} \mathrm{~g}^{-1}$ ),

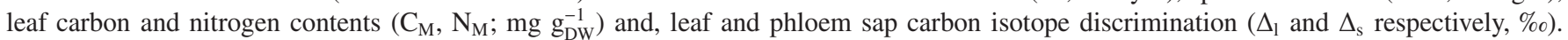
Correlations were computed at genotype level, from 12 poplar genotypes cultivated in alluvial site (above the diagonal line) and from 11 poplar genotypes cultivated in non alluvial site (below the line) in 2005. Significant correlations are indicated in bold (ns = non significant; $* P \leqslant 0.05$; ** $P \leqslant 0.01 ; * * * P \leqslant 0.001$; nd $=$ not determined).

\begin{tabular}{|c|c|c|c|c|c|c|c|c|c|c|c|}
\hline & & \multicolumn{2}{|c|}{ SLA } & \multicolumn{2}{|c|}{$\mathrm{C}_{\mathrm{M}}$} & \multicolumn{2}{|c|}{$\mathrm{N}_{\mathrm{M}}$} & \multicolumn{2}{|c|}{$\Delta_{l}$} & \multirow{2}{*}{$\begin{array}{c}\Delta_{\mathrm{s}} \\
2005\end{array}$} & \multirow[b]{2}{*}{ RI } \\
\hline & & 2005 & 2006 & 2005 & 2006 & 2005 & 2006 & 2005 & 2006 & & \\
\hline \multirow[t]{2}{*}{ SLA } & 2005 & & 0.78** & $-0.46^{\mathrm{ns}}$ & $0.12^{\text {ns }}$ & $0.31^{\mathrm{ns}}$ & $0.50^{\mathrm{ns}}$ & $0.41^{\mathrm{ns}}$ & $0.20^{\mathrm{ns}}$ & $0.48^{\mathrm{ns}}$ & $0.33^{\mathrm{ns}}$ \\
\hline & 2006 & nd & & $-0.16^{\mathrm{ns}}$ & $0.45^{\mathrm{ns}}$ & $0.35^{\mathrm{ns}}$ & $0.67 *$ & $0.31^{\mathrm{ns}}$ & $0.19^{\mathrm{ns}}$ & $0.17^{\mathrm{ns}}$ & $0.35^{\mathrm{ns}}$ \\
\hline \multirow[t]{2}{*}{$\mathrm{C}_{\mathrm{M}}$} & 2005 & $-0.34^{\mathrm{ns}}$ & nd & & $0.45^{\mathrm{ns}}$ & $0.31^{\mathrm{ns}}$ & $0.02^{\mathrm{ns}}$ & $-0.26^{\mathrm{ns}}$ & $0.17^{\mathrm{ns}}$ & $-0.39^{\mathrm{ns}}$ & $0.02^{\text {ns }}$ \\
\hline & 2006 & nd & nd & nd & & $0.65 *$ & $0.47^{\mathrm{ns}}$ & $-0.42^{\mathrm{ns}}$ & $-0.06^{\mathrm{ns}}$ & $-0.49^{\mathrm{ns}}$ & $0.70 *$ \\
\hline \multirow[t]{2}{*}{$\mathrm{N}_{\mathrm{M}}$} & 2005 & $-0.09^{\mathrm{ns}}$ & nd & $0.94 * * *$ & nd & & $0.66^{*}$ & $-0.30^{\mathrm{ns}}$ & $0.03^{\mathrm{ns}}$ & $-0.15^{\mathrm{ns}}$ & $0.48^{\text {ns }}$ \\
\hline & 2006 & nd & nd & nd & nd & nd & & $-0.15^{\mathrm{ns}}$ & $-0.09^{\mathrm{ns}}$ & $-0.16^{\mathrm{ns}}$ & $0.62 *$ \\
\hline \multirow[t]{2}{*}{$\Delta_{1}$} & 2005 & $0.45^{\mathrm{ns}}$ & nd & $-0.86 * *$ & nd & $-0.77 * *$ & nd & & $0.77 * *$ & $0.69 *$ & $0.01^{\mathrm{ns}}$ \\
\hline & 2006 & nd & nd & nd & nd & nd & nd & nd & & $0.43^{\mathrm{ns}}$ & $0.07^{\mathrm{ns}}$ \\
\hline \multirow[t]{2}{*}{$\Delta_{\mathrm{s}}$} & 2005 & $0.41^{\mathrm{ns}}$ & nd & $-0.81 * *$ & nd & $-0.78^{* *}$ & nd & $0.91 * * *$ & nd & & $0.07^{\mathrm{ns}}$ \\
\hline & RI & $0.46^{\mathrm{ns}}$ & nd & $0.49^{\mathrm{ns}}$ & nd & $0.62 *$ & nd & $-0.30^{\mathrm{ns}}$ & nd & $-0.41^{\mathrm{ns}}$ & \\
\hline
\end{tabular}

via SLA) with higher $\mathrm{N}_{M}$ and $\mathrm{C}_{M}$ contents at both sites. The site effect was similar for all variables between hybrid cross except for SLA and $\mathrm{N}_{\mathrm{M}}$; TD hybrids displayed the greatest decline in SLA and $\mathrm{N}_{\mathrm{M}}$ when planted on the non alluvial site compared with DN hybrids. Nevertheless, all these results must be taken cautiously because of the unbalanced number of genotypes within each hybrid cross.

\subsection{Genetic variability of productivity, leaf traits and variables related to water-use efficiency - year and site effects}

Significant genotype variability was observed within each hybrid cross for all traits in alluvial and non alluvial sites. Such genetic variability had already been observed from younger plant material in previous studies in hybrid poplars growing in a glasshouse or in the field (Al Afas et al., 2007; Ceulemans and Deraedt, 1999; Marron et al., 2005; Monclus et al., 2005; 2006; Voltas et al., 2006).

All genotypes grouped, genotypic rankings were comparable between 2005 and 2006 for most of the variables measured from the alluvial site showing stability overtime in genetic variability. Such stability over 2 years had already been observed in nursery from 3-year-old rooted cuttings of $29 \mathrm{DN}$ hybrid genotypes (Monclus et al., 2006). $\Delta_{1}$ and SLA increased between 2005 and 2006; these variations can be attributed to inter-annual climatic changes and more particularly, to higher cumulated rainfall measured in 2006 than in $2005(350 \mathrm{~mm}$ vs. $224 \mathrm{~mm}$ ). Such environmental effects had similarly been observed by Monclus et al. (2006).

In 2005, a significant interaction between genotype in hybrid cross and site was detected for all variables. Taking into account that each genotype displayed the same age between alluvial and non alluvial sites, these results suggest that the effect of soil fertility and soil water availability on productivity, on variables related to WUE and on leaf traits strongly depends on the genotype. As a whole, RI was clearly larger in the alluvial site than in the non alluvial one; this can be easily explained by higher soil fertility and soil water availability in the alluvial site. Differences between sites were corroborated by differences in some leaf traits such as SLA and $\mathrm{N}_{\mathrm{M}}$. The lowest values of SLA and $\mathrm{N}_{\mathrm{M}}$ measured in the non alluvial site can be ascribed to lower soil water availability and fertility (Abrams et al., 1990; Cunningham et al., 1999; Li et al., 2005; Marron et al., 2002; Monclus et al., 2006; Niinemets et al., 1998; Poorter and de Jong, 1999). $\mathrm{N}_{M}$ decreased between alluvial and non alluvial sites while genotypic ranking remained stable suggesting that $\mathrm{N}_{\mathrm{M}}$ variations mainly depended on the environment.

It is noteworthy that the genotype ranking was maintained for $\Delta_{1}$ between experiments conducted in a glasshouse and in the alluvial station only. In both cases, plants grown on fertilized and well-watered soils and the collected leaves were exposed to low irradiance. Therefore, the genotype ranking for $\Delta_{1}$ was conserved regardless of the age of the plants whereas it strongly varied for plants of similar age when grown under contrasting environmental conditions. Further experiments are needed to build a consistent data basis for age and site related effects on genotype rankings for $\Delta$.

\subsection{Relationships between productivity, leaf traits and variables related to WUE}

Although $\Delta_{1}$ was estimated from leaves located on the lowest branches and thus from shade leaves, a strong and positive relationship was observed between $\Delta_{1}$ and $\Delta_{\mathrm{S}}$ during 2005, for both sites. While $\Delta_{1}$ is an integrative indicator of intrinsic water-use efficiency at a leaf life time-scale (Farquhar and Richards, 1984), $\Delta_{\mathrm{S}}$ integrates the whole canopy but may reflect short-term fluctuations of $\mathrm{C}_{\mathrm{i}} / \mathrm{C}_{\mathrm{a}}$ (Cernusak et al., 2003; 


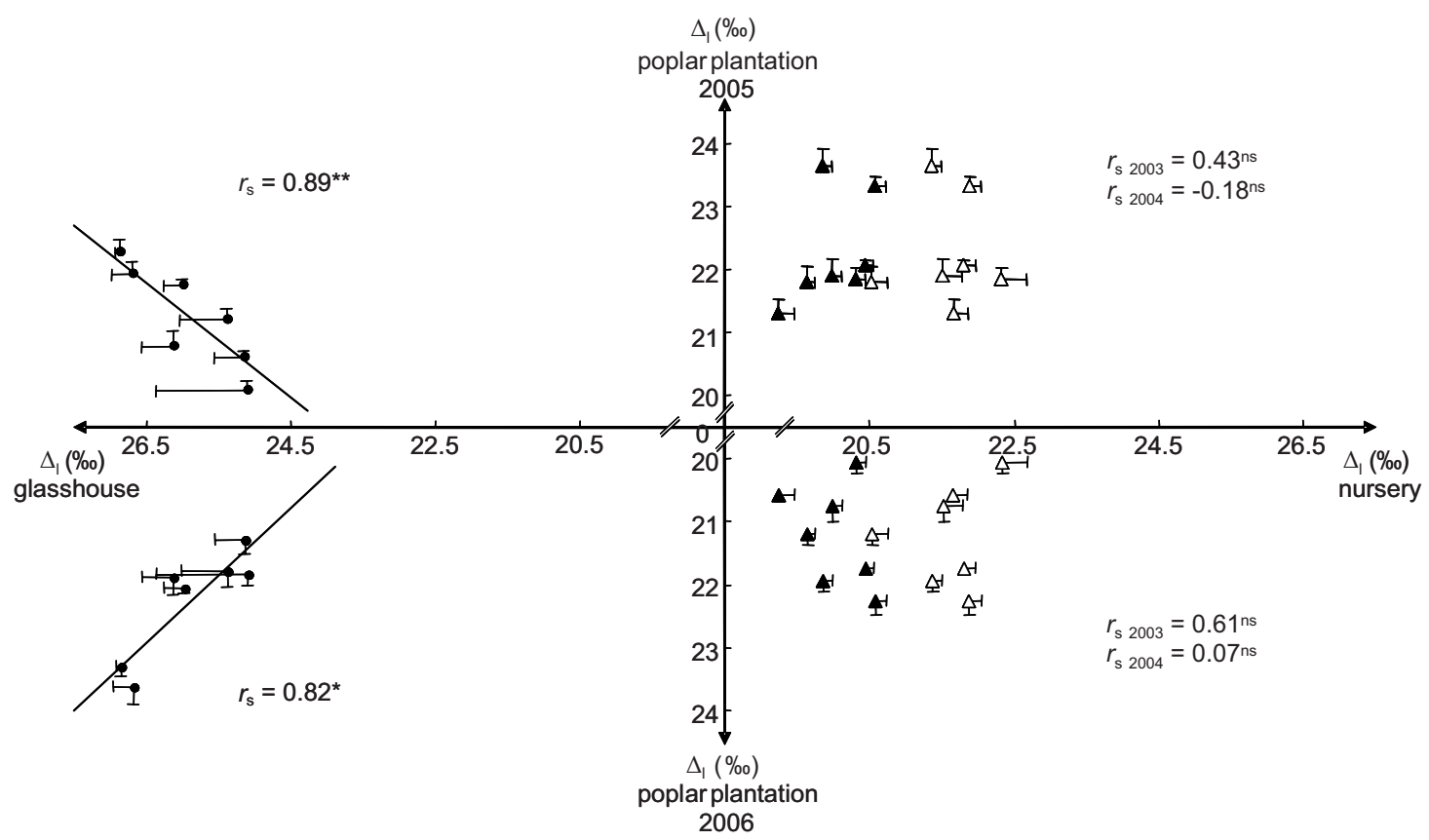

Figure 3. Relationship between leaf carbon isotope discrimination $\left(\Delta_{1}, \%\right.$ ) measured in the alluvial site in 2005 and 2006 , and leaf carbon isotope discrimination measured for the same genotypes in glasshouse in 2001 (black circles) (Marron et al., 2005) and in nursery in 2003 (black triangles) (Monclus et al., 2005) and 2004 (White triangles) (Monclus et al., 2006). Glasshouse and nursery measurements had been recorded from plants grown under well-watered condition. Genotypic means \pm standard error are indicated $(n=7)$. Rank correlations $($ Spearman coefficients, $r_{s}$ ) are indicated with level of significance (ns = non significant; * $P \leqslant 0.05 ; * * P \leqslant 0.01$ ).

Gessler et al., 2001; Keitel et al., 2003; Pate and Arthur, 1998). This similarity is remarkable with respect to the potential causes for differences in measurements at such different time and spatial scales. Nevertheless, as previously shown for mature leaves, $\Delta_{1}$ could be an accurate predictor of the carbon isotope signature of the whole canopy (Cernusak et al., 2003; Gessler et al., 2001; Pate and Arthur, 1998).

No relationship has been observed between productivity and variables related to water-use efficiency $(\Delta)$, as previously described for Populus fremontii (Leffler and Evans, 1999), for TD hybrids (Rae et al., 2004) and for DN hybrids (Marron et al., 2005; Monclus et al., 2005; 2006; Voltas et al., 2006). The lack of correlation between productivity and water-use efficiency observed earlier on young individuals was thus confirmed at larger ages and sizes, and under very different growth conditions. From a practical point of view, these results support the idea that there is a potential for improving intrinsic water-use efficiency in poplar without necessarily reducing overall productivity. In 2005, RI scaled positively with $\mathrm{N}_{\mathrm{M}}$ in the non alluvial site only; this result suggests that $\mathrm{N}_{\mathrm{M}}$ would be a limiting factor for productivity in the non alluvial site. A negative correlation was observed between $\Delta$ and $\mathrm{N}_{\mathrm{M}}$ in the non alluvial site suggesting that genetic variability of photosynthetic capacity could also contribute to WUE variability (Monclus et al., 2005; 2006). As already shown in the nursery studies, $\Delta$ did not correlate with SLA, suggesting that the variability of $\Delta$ cannot be explained by genotype variations in internal conductance to $\mathrm{CO}_{2}$ transfer into the leaves, which may be greater in thicker leaves.

\section{CONCLUSIONS}

Experiments were conducted with DN and TD hybrids older than five years and grown in alluvial and non alluvial sites in a commercial poplar plantation. A large genetic variability in productivity, leaf traits and variables related to WUE was observed from mature trees, similar to that previously observed from young cuttings cultivated in glasshouse or in nursery. The genotypic ranking for WUE was maintained between young cuttings grown in glasshouse and trees grown in the alluvial site, while it was broadly disrupted for trees of similar age when grown on contrasting sites. No correlation was detected between productivity and $\Delta$, as previously observed in a glasshouse or in a nursery, supporting the conclusion that there is a potential for improving WUE in poplar without necessarily reducing overall productivity. Interestingly for European poplar growers, we were able to detect one genotype, Soligo, combining a satisfactory productivity and a large WUE whatever the site. Moreover, we were also able to put forward one genotype, Dorskamp, combining a satisfactory productivity and low WUE in the alluvial site only; this latter genotype could be used as a medium for phytoremediation of polluted soils.

Acknowledgements: Ludovic Bonhomme was supported by a Ph.D. grant from the Conseil Régional, Région Centre, France. This research was funded by the Biotechnocentre association supported by the Conseil Régional, Région Centre. The poplar plantation was kindly provided by $\mathrm{D}$. Meese. The authors gratefully acknowledge the 
excellent technical assistance of Alain Guichard, Isabelle Lejan and Gilles Moreau (Laboratoire de Biologie des Ligneux et des Grandes Cultures). We also acknowledge Claude Bréchet from UMR EEF at INRA of Nancy and Annie-Claude Roche from CBM at CNRS of Orléans, who graciously made their respective laboratories available.

\section{REFERENCES}

Abrams M.D., Kubiske M.E., and Steiner K.C., 1990. Drought adaptations and responses in five genotypes of Fraxinus pennsylvanica Marsh: photosynthesis, water relations and leaf morphology. Tree Physiol. 6: 305-315.

Al afas N., Marron N., and Ceulemans R., 2007. Variability in Populus leaf anatomy and morphology in relation to canopy position, biomass production, and varietal taxon. Ann. For. Sci. 64: 521-532.

Barigah T.S., Saugier B., Mousseau M., Guittet J., and Ceulemans R., 1994. Photosynthesis, leaf area and productivity of five poplar clones during their establishment year. Ann. For. Sci. 51: 613-625.

Braatne J.H., Hinckley T.M., and Stettler R.F., 1992. Influence of soil water on the physiological and morphological components of plant water balance in Populus trichocarpa, Populus deltoides and their F1 hybrids. Tree Physiol. 11: 325-339.

Cernusak L.A., Arthur D.J., Pate J.S., and Farquhar G.D., 2003. Water relations link carbon and oxygen isotope discrimination to phloem sap sugar concentration in Eucalyptus globulus. Plant Physiol. 131: $1544-1554$.

Ceulemans R. and Deraedt W., 1999. Production physiology and growth potential of poplars under short-rotation forestry culture. For. Ecol. Manage. 121: 9-23.

Ceulemans R., Impens I., and Steenackers V., 1988. Genetic variation in aspects of leaf growth of Populus clones, using the leaf plastochron index. Can. J. For. Res. 18: 1069-1077.

Condon A.G., Richards R.A., Rebetzke G.J., and Farquhar G.D., 2002. Improving intrinsic water-use efficiency and crop yield. Crop Sci. 42: $122-131$

Craig H., 1957. Isotopic standards for carbon and oxygen and correction factors for mass-spectrometric analysis of carbon dioxide. Geochim. Cosmochim. Ac. 12: 133-149.

Cunningham S.A., Summerhayes B., and Westoby M., 1999. Evolutionary divergences in leaf structure and chemistry, comparing rainfall and soil nutrient gradients. Ecol. Monogr. 69: 569-588.

Farquhar G.D. and Richards R.A., 1984. Isotopic composition of plant carbon correlates with water-use efficiency of wheat genotypes. Aust. J. Plant Physiol. 11: 539-552.

Farquhar G.D., Ehleringer J.R., and Hubick K.T., 1989. Carbon isotope discrimination and photosynthesis. Annu. Rev. Plant Physiol. Plant Mol. Biol. 40: 503-537.

Gessler A., Schrempp S., Matzarakis A., Mayer H., Rennenberg H., and Adams M.A., 2001. Radiation modifies the effect of water availability on the carbon isotope composition of beech (Fagus sylvatica). New Phytol. 150: 653-664.

Gessler A., Rennenberg H., and Keitel C., 2004. Stable isotope of organic compounds transported in the phloem of European beech-evaluation of different methods of phloem sap collection and assessment of gradients in carbon isotope composition during leaf-to-stem transport. Plant Biol. 6: 1-9.

Jamagne M., Bétrémieux R., Bégon J.C., and Mori A., 1977. Quelques données sur la variabilité dans le milieu naturel de la réserve en eau des sols. Bulletin Technique d'Information 324-325: 627-641.

Keitel C., Adams M.A., Holst T., Matzarakis A., Mayer H., Rennenberg H., and Gessler A., 2003. Carbon and oxygen isotope composition of organic compounds in the phloem sap provides a short-term measure for stomatal conductance of European beech (Fagus sylvatica L.). Plant Cell Environ. 26: 1157-1168.
Leffler A.J. and Evans A.S., 1999. Variation in carbon isotope composition among years in the riparian tree Populus fremontii. Oecologia 119: 311-319.

Li Y., Johnson D.A., Su Y., Cui J., and Zhang T., 2005. Specific leaf area and leaf dry matter content of plants growing in sand dunes. Bot. Bull. Acad. Sinica 46: 127-134.

Marron N., Delay D., Petit J.M., Dreyer E., Kahlem G., Delmotte F.M., and Brignolas F., 2002. Physiological traits of two Populus $\times \mathrm{eu}$ ramericana clones, Luisa Avanzo and Dorskamp, during a water stress and re-watering cycle. Tree Physiol. 22: 849-858.

Marron N., Villar M., Dreyer E., Delay D., Boudouresque E., Petit J.M., Delmotte F.M., Guehl J.M., and Brignolas F., 2005. Diversity of leaf traits related to productivity in 31 Populus deltoides $\times$ Populus nigra clones. Tree Physiol. 25: 425-435.

Monclus R., Dreyer E., Delmotte F.M., Villar M., Delay D., Boudouresque E., Petit J.-M., Marron N., Bréchet C., and Brignolas F., 2005. Productivity, leaf traits and carbon isotope discrimination in 29 Populus deltoides $\times$ P. nigra clones. New Phytol. 167: 53-62.

Monclus R., Dreyer E., Villar M., Delmotte F.M., Delay D., Petit J.M., Barbaroux C., Le Thiec D., Bréchet C., and Brignolas F., 2006. Impact of drought on productivity and water use efficiency in 29 genotypes of Populus deltoides $\times$ Populus nigra. New Phytol. 169: $765-777$.

Niinemets Ü., Kull O., and Tenhunen J.D., 1998. An analysis of light effects on foliar morphology, physiology, and light interception in temperate deciduous woody species of contrasting shade tolerance. Tree Physiol. 18: 681-696.

Pate J. and Arthur D., 1998. $\delta^{13} \mathrm{C}$ analysis of phloem sap carbon: novel means of evaluating seasonal water stress and interpreting carbon isotope signatures of foliage and trunk wood of Eucalyptus globulus. Oecologia 117: 301-311.

Ponton S., Dupouey J.L., Bréda N., Feuillat F., Bodenes C., and Dreyer E., 2001. Carbon isotope discrimination and wood anatomy variations in mixed stands of Quercus robur and Quercus petraea. Plant Cell Environ. 24: 861-868.

Poorter H. and de Jong R., 1999. A comparison of specific leaf area, chemical composition and leaf construction costs of field plants from 15 habitats differing in productivity. New Phytol. 143: 163-176.

Rae A.M., Robinson K.M., Street N.R., and Taylor G., 2004. Morphological and physiological traits influencing biomass productivity in short-rotation coppice poplar. Can. J. For. Res. 34: 14881498.

Scartazza A., Mata C., Matteucci G., Yakir D., Moscatello S., and Brugnoli E., 2004. Comparisons of $\delta^{13} \mathrm{C}$ of photosynthetic products and ecosystem respiratory $\mathrm{CO}_{2}$ and their responses to seasonal climate variability. Oecologia 140: 340-351.

Tschaplinski T.J. and Blake T.J., 1989. Water relations, photosynthetic capacity, and root/shoot partitioning of photosynthetic as determinants of productivity in hybrid poplar. Can. J. Bot. 67: 1689-1697.

Tschaplinski T.J., Tuskan G.A., and Gunderson C.A., 1994. Water-stress tolerance of black cottonwood and eastern cottonwood clones and four of their hybrid progeny. I. Growth, water relations and gas exchange. Can. J. For. Res. 24: 364-371.

Voltas J., Serrano L., Hernandez M., and Peman J., 2006. Carbon isotope discrimination, gas exchange and stem growth of four Euramerican hybrid poplars under different watering regimes. New For. 31: 435451.

Zhang X., Zang R., and Li C., 2004. Population differences in physiological and morphological adaptations of Populus davidiana seedlings in response to progressive drought stress. Plant Sci. 166: 791-797.

Zsuffa L., Giordano E., Pryor L.D., and Stettler R.F., 1996. Trends in poplar culture: some global and regional perspectives. In: Stettler R.F., Bradshaw H.D. Jr., Heilman P.E., and Hinckley T.M. (Eds.), Biology of Populus and its Implications for Management and Conservation, NRC-CNRC, Ottawa, pp. 515-539. 


\section{APPENDIX}
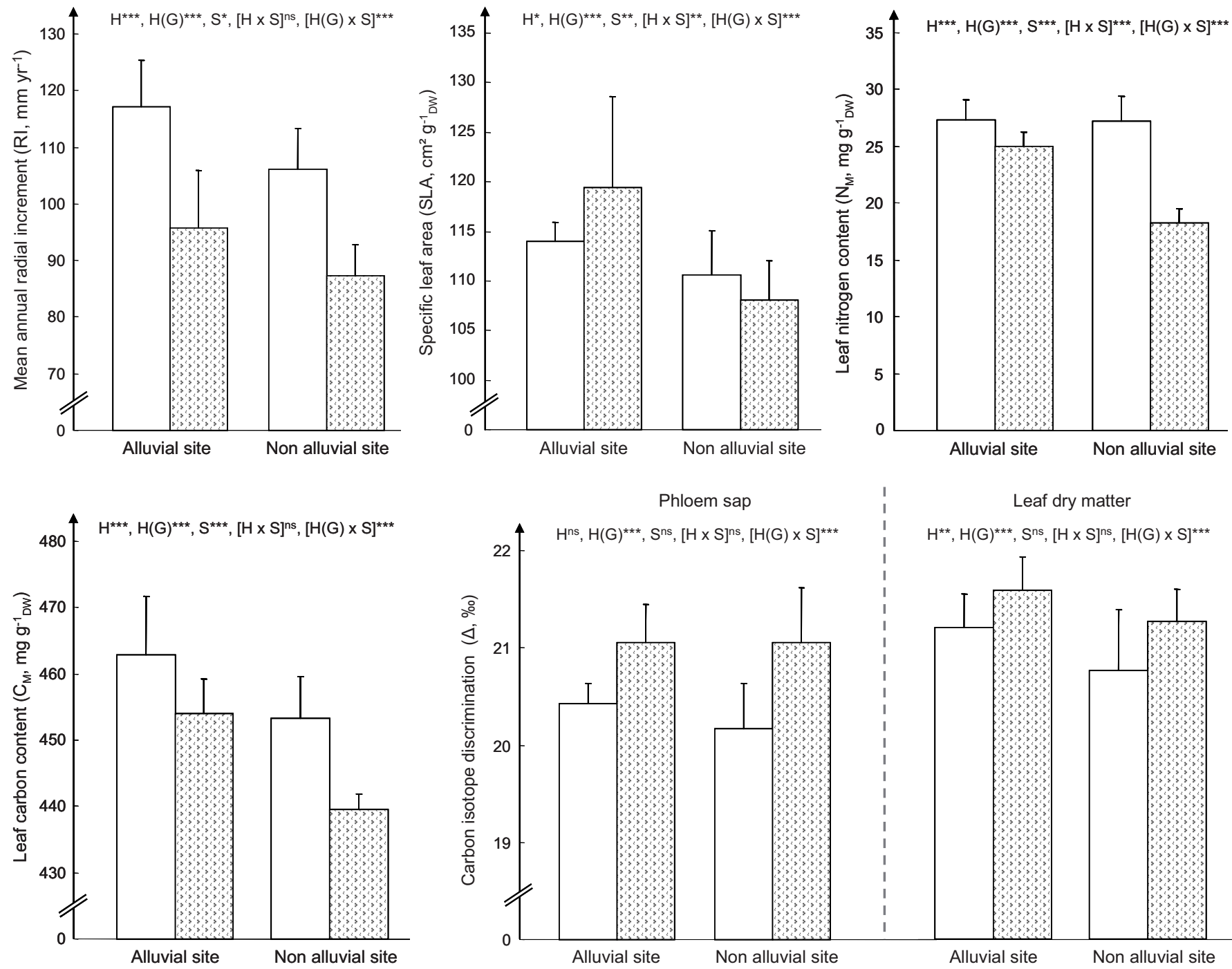

Appendix A1. Comparison between alluvial and non alluvial sites for mean annual radial increment (RI, mm $\mathrm{y}^{-1}$ ) specific leaf area (SLA, $\left.\mathrm{cm}^{2} \mathrm{~g}_{\mathrm{DW}}^{-1}\right)$, leaf nitrogen and carbon contents $\left(\mathrm{N}_{\mathrm{M}}\right.$ and $\left.\mathrm{C}_{\mathrm{M}}, \mathrm{mg} \mathrm{g}_{\mathrm{DW}}^{-1}\right)$, and leaf dry matter and phloem sap carbon isotope discrimination $(\Delta, \%$, $)$ Comparison was performed from 9 hybrid poplars (5 DN hybrids (white bars) and 4 TD hybrids (hyphenated bars)) common to the two sites. Means \pm standard errors were presented for each site. Levels of significance are indicated for the hybrid cross effect $(\mathrm{H})$, for the genotype in hybrid cross effect $[\mathrm{H}(\mathrm{G})]$, for the site effect $(\mathrm{S})$, for the hybrid cross by site interaction $(\mathrm{H} \times \mathrm{S})$ effect and for the genotype in hybrid cross by site interaction $[\mathrm{H}(\mathrm{G}) \times \mathrm{S}]$ effect $(\mathrm{ns}=$ non significant; $* P \leqslant 0.05 ; * * P \leqslant 0.01 ; * * * P \leqslant 0.001)$. 